\title{
KEHADIRAN PEMILIH DI TPS (TEMPAT PEMUNGUTAN SUARA) DALAM PILKADA SERENTAK BULAN DESEMBER TAHUN 2020
}

\section{Santosa}

Widyaiswara Ahli Madya BPSDM Jawa Tengah, Indonesia

Email: sekarlangits@yahoo.co.id

\section{Abstract}

This study aims to analyze how the level of Voter Attendance at polling stations (TPS) in the December 2020 Regional Elections coincided with the COVID-19 Pandemic. The method used in this research is survey research with cross sectional research design through questionnaires distributed using google form distributed through Watshap Group that can reach out of Java for four days with creteria that at that time the region held simultaneous elections. The sample used in this study was probabilitysampling. The population in this study was all 130 respondents who filled google from being used as respondents. Conclusion On Characteristic Variables, novice respondents are still low at 5 (3.8\%) first-time respondents participated in the Simultaneous Elections, in line with the age indicatorthat the age of novicevoters is usi a 17 Years - 20 Years obtained 1 (0.8\%) Respondents. In the concurrent Election Variables that the attendance rate is $120(92.3 \%)$ respondents stated that they were present at the polling station to exercise their voting rights in the 2020 Regional Elections. In the Covid 19 Pandemic Variable,respondents currentlynumber $85(65.4 \%)$ respondents stated in the Red Zone and Health Protocol in tps number 95 (73.1\%) respondents stated Already and Very Maximal in applying Prokes in tps where respondents choose.

Keywords: simultaneous piklada 2020; presence; COVID-19 pandemic

\section{Abstrak}

Penelitian ini bertujuan menganalisis bagaimana tingkat Kehadiran Pemilih di Tempat Pemungutan Suara (TPS) dalam Pemilihan Kepala Daerah (Pilkada) Serentak Bulan Desember Tahun 2020 yang bertepatan suasananya masih di Masa Pandemi COVID-19. Metode yang digunakan dalam penelitian ini adalah penelitian survey dengan desain penelitian cross sectional melalui kuesioner yang dibagikan menggunakan google form yang di sebarkan melalui Whatshap Group yang dapat menjangkau sampai diluar jawa selama empat hari dengan kreteria yang saat itu daerahnya melaksanakan Pilkada Serentak. Sampel yang digunakan dalam penelitian ini adalah probability sampling. Populasi dalam penelitian ini adalah seluruh responden sejumlah 130 yang mengisi google from dijadikan sebagai responden. Kesimpulan Pada Variabel Karakteristik, responden pemula masih rendah yaitu $5(3,8 \%)$ responden baru pertama kali mengikuti Pilkada Serentak, selaras dengan indikator usia bahwa usia pemilih pemula yaitu usia 17 Tahun - 20 Tahun didapatkan $1(0,8 \%)$ responden. Pada Variabel Pilkada serentak bahwa tingkat Kehadiran di dapatkan $120(92,3 \%)$ responden menyatakan Hadir di TPS 
untuk menggunakan Hak Pilihnya di Pilkada Serentak Tahun 2020. Pada Variabel Pandemi Covid 19, daerah responden saat ini sejumlah 85(65,4\%) responden menyatakan pada Zona Merah dan Protokol Kesehatan di TPS sejumlah $95(73,1 \%)$ responden menyatakan Sudah dan Sangat Maksimal dalam menerapkan Prokes di TPS tempat responden memilih.

Kata kunci: piklada serentak 2020; kehadiran; pandemi Covid-19

\section{Pendahuluan}

Coronavirus adalah sekumpulan virus dari subfamili Orthocronavirinae dalam keluarga Coronaviridae dan ordo Nidovirales. Kelompok virus ini yang dapat menyebabkan penyakit pada burung dan mamalia, termasuk manusia. Pada manusia, coronavirus menyebabkan infeksi saluran pernapasan yang umumnya ringan, seperti pilek, meskipun beberapa bentuk penyakit seperti; SARS, MERS, dan COVID-19 sifatnya lebih mematikan (Pratiwi, Mulamukti, Pertiwi, \& Andriany, 2020).

Dalam kondisi saat ini, virus corona bukanlah suatu wabah yang bisa diabaikan begitu saja. Jika dilihat dari gejalanya, orang awam akan mengiranya hanya sebatas influenza biasa, tetapi bagi analisis kedokteran virus ini cukup berbahaya dan mematikan. Saat ini di tahun 2020, perkembangan penularan virus ini cukup signifikan karena penyebarannya sudah mendunia dan seluruh negara merasakan dampaknya termasuk Indonesia (Yunus \& Rezki, 2020).

Dunia saat ini beradu cepat dengan Covid-19 atau tepatnya masih berjibaku dengan Pandemi yang belum kita ketahui kapan berakhirnya. Pandemi ini telah menyita pikiran dan atensi yang tinggi sehingga menyebabkan krisis tata kelola serta kebijakan penindakan pandemi di negara lain di dunia (Mas'udi \& Winanti, 2020). Nyaris disetiap negera dimanapun, baik negera yang sedang tumbuh ataupun negera maju yang secara teknologinya, serta ekonominya dianggap profesional serta mumpuni dalam pelayanan fasilitas kesehatan, dimana era sekarang ini tengah mengalami ketidakpastian serta ketidakyakinan dalam menanggulangi wabah COVID-19. Dampak COVID-19 secara nyata sudah terlihat tidak hanya mempengaruhi terhadap sektor kesehatan publik, tetapi juga banyak sektor lain mulai dari ekonomi, pendidikan, budaya, sosial, politik, hingga pemerintahan. Secara khusus dalam bidang politik. Pandemi COVID-19 di Indonesia telah mengakibatkan juga Jadwal Pemilihan Kepala Daerah (Pilkada) 2020 mengalami penundaan. Pemerintah, Dewan Perwakilan Rakyat (DPR) RI dan Komisi Pemilihan Umum (KPU) menyepakati untuk menunda Pilkada 2020 sampai bulan Desember 2020. Pemerintah melalui KPU juga telah mengeluarkan Peraturan Pemerintah Pengganti Undang-Undang (Perppu) No. 2 Tahun 2020 sebagai pedoman penyelenggaraan pemilihan kepala daerah tahun ini (Kennedy \& Suhendarto, 2020). Perdebatan dengan diputuskannya untuk tetap menyelenggarakan Pilkada Serentak 2020 di tengah pandemi telah menimbulkan kekhawatiran dan permasalahan sosial di tengah masyarakat, terutama di kalangan pakar dan akademisi. Keputusan untuk melaksanakan pilkada di bulan Desember 2020 banyak yang beranggapan bahwa tidak realistis dan penuh dengan risiko yang berdampak pada petugas, pemilih dan calon yang dipilih disaat 
pelaksanaan kampanye, mengingat jumlah kasus positif COVID-19 di Indonesia terus meningkat secara nasional (Kennedy \& Suhendarto, 2020). Sementara itu, berbagai macam proyeksi dari para pakar (ahli) kesehatan masyarakat ataupun ahli kesehatan tentang virologi juga epidemilogi belum memberi sinyal yang pasti sampai kapan pandemi COVID-19 ini akan berakhir (Wardhana, 2020).

Berdasarkan data yang ada bahwa hingga tanggal 30 November 2020 Kasus positif Covid-19 bertambah 4.617 menjadi 538.883 kasus. Pasien sembuh bertambah 4.725 menjadi 450.518 orang. Pasien meninggal bertambah 130 menjadi 16.945 orang. Data tersebut meningkat secara signifikan dibandingkan data Kasus positif Corona pada tanggal 1 November 2020 dimana pertambahan kasus di angka 2.696 menjadi 412.784 kasus. Pasien sembuh bertambah 4.141 menjadi 341.942 pasien. Pasien meninggal dunia bertambah 74 menjadi 13.943 orang (Merdeka.com.2020). Sebenarnya dengan Data Kasus COVID-19 yang masih tinggi, banyak pihak mengkhawatirkan apabila Pilkada harus tetap diselenggarakan pada bulan Desember 2020, hal ini di takutkan justru akan menjadi permasalahan baru tentang penyebaran yang dapat berpotensi secara teoritis menjadi klaster baru penyebaran COVID-19 dan akan mendorong terjadinya serangan gelombang kedua wabah COVID-19 di Indonesia. Ketakutan dan kekawatiran yang ada tidak hanya itu, di prediksikan bahwa Pilkada Serentak 2020 juga akan mengalami degradasi kualitas yang disebabkan oleh menurunnya angka partisipasi masyarakat dalam memberikan hak pilihnya di Tempat Pemungutan Suara (TPS). Gairah Pesta Demokrasi selama ini yang ada di masyarakat juga diprediksi akan menurun sebagai dampak pandemi COVID-19 yang menimbulkan ketakutan juga ketidakpercayaan dalam diri masyarakat apabila ingin ikut berpartisipasi dalam setiap tahapan atau proses Pilkada serentak.

Politik bagi sebagian orang menjadi tema yang malas untuk didiskusikan. Politik dianggap kotor, kebohongan, licik bahkan bentuk penindasan kepada kelompok lain. Mindset tersebut menguasai diri seseorang dan berakibat pada sikap apatis atau acuh, cuek, tidak peduli terhadap politik yang berlangsung dinegaranya. Salah satu bentuk kekecewaan terhadap politik, diwujudkan dengan tidak ikut berpartisipasi dalam politik yang menamai diri sebagai Golongan Putih (Golput) (Saputro, 2018).

Penyelenggaraan Pemilihan Kepala Daerah (Pilkada) sejatinya merupakan bagian penting kehidupan bernegara Indonesia di era Reformasi (Sutrisno, 2017).

Penyelenggaraan Pilkada Serentak 2020 disatu sisi pula sangat berarti sebab menjadi bagian dari amanat yang sudah tertuang pada Undang- Undang Nomor. 10 Tahun 2016 Pasal 201 Ayat 6. Penerapan Pilkada Serentak adalah konsekuensi dari suatu sistem demokrasi Indonesia yang dianut, yang bertujuan mewujudkan re- genarisi kepemimpinan secara adil, bijaksana, dan cocok dengan syarat yang tertuang dalam konstitusi. Tahun 2020 dan awal 2021 ini banyak masa kepemimpinan Gubernur,Walikota serta Bupati yang habis masa jabatannya, sedangkan kedudukan serta posisi dari kepala wilayah tersebut sangat diperlukan guna sinergitas serta bekerjasama dengan pemerintah pusat dalam melakukan lompatan lompatan strategis dalam penindakan COVID- 19 dan proses pemulihan pasca COVID-19, hal ini 
nampaknya yang menjadi pertimbangan Pilkada Serentak diupayakan tetap dilaksanakan pada Tahun 2020 ini. Sesungguhnya, proses ini dapat saja bisa disiasatu dengan Penunjukan Pelaksana Jabatan (PJ), namun dikira kurang efisien sebab kewenangan yang dipunyai oleh PJ sangat terbatas, sehingga dapat memperlambat kinerja dan juga berdampak pada suhu politik di daerah

Pengalaman dari Negara Korea Selatan dan negara negara lain yang berhasil melaksanakan pemilu ditengah Pandemi Covid-19 sebenarnya bisa dijadikan rekomendasi Indonesia. Komitmen yang luar biasa dari semua pihak harus diwujudkan secara komprehensif oleh seluruh aparatur komisi pemilihan umum yang didalamnya adalah kematangan mekanisme, ketersediaan APD (Alat Pelindung Diri), kemampuan dan ketercukupan biaya penyelenggaraan demi suksesnya gawe besar pemilihan umum, serta berbagai antisipasi situasi jika dibutuhkan dan juga harus dirancang serta disimulasikan secara matang. Negara harapannya harus benar-benar hadir dalam menjamin kesuksesan pelaksanaan Pilkada dan keselamatan warga negara Indonesia. Proses penyelenggaraan diharapakan dari awal hingga pemungutan suara dapat berjalan dengan lancar dan sukses, serta masyarakat juga dijamin keamanannya dari ancaman Covid-19. Harapan kedepan yang tidak kalah pentingnya Pilkada Serentak 2020 dapat memunculkan pemimpin-pemimpin yang berkualitas, adil, bijaksana, dan demokratis pasca Covid-19.

Penelitian yang sama terkait dengan Pilkada sererntak pernah dilakukan pada tahun 2018 dengan obyek peneletian pada Pilkada Serentah Tahun 2015 dengan judul Partisipasi Politik Masyarakat Pada Pilkada Serentak 2015 Di Kabupaten Gowa (Studi Terhadap Pemilih Pemula Di Kel.Batang Kaluku Kec.Somba Opu Kab.Gowa). Dalam penelitian tersebut menyimpulkan bahwa partisipasi politik masyakat pemilih pemula di kelurahan Batang Kaluku sudah sangat baik (aktif) yang dapat dilihat dari tingginya keinginan masyarakat pemilih pemula untuk ikut serta dalam proses pemilihan pilkada, dengan harapan sosok pemimpin yang terpilik nantinya dapat membawa daerah mereka lebih baik lagi. Serta minimnya Pendidikan politik yang di berikan pemerintah yang bersangkutan terhadap pemilih pemula agar dapat melibatkan pemilih pemula secara efektif yang akan memperkuat dan mempermudah partai politik dan penyelenggara pemilu pada langkah tindak selanjutnya (Ahclak Asmara, 2018).

Berdasarkan uraian tersebut diatas, pada penelitian ini peneliti tertarik membahas akan tingkat kehadiran secara menyeluruh dengan tiga variabel yaitu Karakteristik Responden, Pilkada Serentak dan Pandemi Covid-19,sehingga dapat dikatakan penelitian ini adalah terbaru karena bersama dengan situasi pandemi, untuk itu peneliti bertujuan ingin menganalisis bagaimana tingkat Kehadiran Pemilih di Tempat Pemungutan Suara (TPS) dalam Pemilihan Kepala Daerah (Pilkada) Serentak pada Bulan Desember Tahun 2020 yang bertepatan suasananya masih di Masa Pandemi COVID-19.

UU No 6 Tahun 2020 tentang Penetapan Perppu No. 2 Tahun 2020 tentang Pilkada 2020 di Masa Pandemi COVID-19, ada 3 perubahan mendasar yang diatur didalamnya yaitu Pertama, Pasal 120 yang menyatakan faktor bencana non-alam 
sebagai alasan penundaan rangkaian Pilkada. Kedua, Pasal 122 A berkenaan dengan penundaan dan penetapan Pilkada lanjutan ditetapkan berdasarkan kesepakatan Pemerintah, DPR RI, dan KPU. Ketiga, Pasal 201A Pilkada yang pada awalnya akan dilaksanakan pada bulan September 2020 ditunda dan akan diselenggarakan pada bulan Desember 2020, dengan alasan bencana non-alam pandemi Covid-19. Apabila pada bulan Desember 2020 pilkada belum dapat dilakukan, maka bisa ditunda kembali sesuai ketentuan yang tercantum pada Pasal 122A. Namun demikian, Pasal 201A Perppu No. 2 Tahun 2020 sebagai open legal policy (kebijakan hukum terbuka) masih memungkinkan terjadinya perubahan, yakni penundaan kembali pilkada lanjutan apabila situasi pandemi Covid-19 belum mereda.

Negara Korea Selatan telah suskes melaksanakan pemilu di masa Pandemi Covid19 dan dalam melaksanakan pemilu Korea Selatan tidak lepas dari tiga faktor utama, yakni sistem pemilu yang baik, penanganan Covid-19 yang cepat dan tepat, serta kepercayaan masyarakat terhadap penyelenggara yang tinggi (katadata.co.id, 2020) Sistem pemilu yang baik di Korea Selatan tidak lepas dari upaya pemerintahnya untuk membangun regulasi dan mekanisme penyelenggaraan pemilu dalam kondisi darurat, yaitu melakukan pemungutan awal melalui surat dan sebelum hari pencoblosan, serta diatur jauh hari sebelum wabah. Pemilih dapat hadir ke TPS dua hari sebelum hari pelaksanaan untuk menghindari terjadinya kerumunan orang di TPS. Sedangkan memilih dengan surat yaitu dengan mengisi blanko surat suara dari rumah yang dikirim lewat kantor pos ke alamat penyelenggara pemilu. Kedua mekanisme ini terbukti berhasil mencegah terjadinya kerumunan massa. Anggaran pemilu Korsel juga sangat memadai guna menunjang berjalannya sistem ini, seperti untuk penyediaan Alat Pelindung Diri (APD), hand sanitizer, pengecek suhu tubuh, dan perlengkapan lain yang dapat mencegah penularan Covid-19.

Dengan sistem pemilu yang terencana dengan baik dan tingkat kewaspadaan yang tinggi, kecepatan serta ketepatan dalam penanganan Covid-19, akan membuat masyarakat lebih percaya terhadap penyelenggara pemilu. Masyarakat akan lebih tenang dan yakin bahwa pemilu dapat berjalan lancar dan tidak menyebabkan klaster baru penyebaran Covid-19. Hal ini akan berdampak juga pada situasi politik semakin stabil dan kondusif sehingga membuat masyarakat semakin semangat untuk menyalurkan hak pilihnya serta mempunyai kesadaran tinggi dan rasa bangga menjadi bagian dari kelancaran dan keberhasilan pesta demokrasi tersebut. Penyelenggaraan pemilu di Korea Selatan juga berlangsung transparan dimana media dan televisi diundang melakukan siaran langsung dari TPS. Dengan begitu, masyarakat dapat mengetahui proses penghitungan suara dari tempat tinggalnya masing-masing tanpa rasa khawatir hak suaranya hilang atau terjadi kecurangan.

Komisi Pemilihan Umum (KPU) telah menyusun tata cara pemungutan suara di tempat pemungutan suara (TPS) pada pelaksanaan Pilkada 2020 di masa pandemi Covid-19 sesuai dengan kewenangan yang dimilikinya. Komisoner KPU mengilustrasikan, dimana pada saat kedatangan para pemilih akan mengantre terlebih dahulu dengan menjaga jarak aman. Tata Cara Pemungutan dan Penghitungan Suara 
pada Pemilihan Serentak Lanjutan dalam Kondisi Bencana Nonalam Covid-19, juga diatur dimana petugas ketertiban akan mengimbau pemilih untuk mencuci tangan dan menggunakan masker serta mengecek suhu tubuh pemilih. Selanjutnya, pemilih juga wajib mengisi formulir $\mathrm{C}$, daftar hadir-KWK, kemudian petugas Kelompok Penyelenggara Pemungutan Suara (KPPS) memberikan sarung tangan kepada pemilih.. Tahapan selanjutnya pemilih menyerahkan formulir C, pemberitahuan-KWK dan eKTP atau surat keterangan kepada KPPS. Setelah itu, pemilih menggunakan sarung tangan dan menunggu giliran dipanggil di kursi yang telah disediakan dengan tetap menjaga jarak. Ketua KPPS memanggil pemilih untuk mengambil surat suara. Kemudian pemilih memeriksa kondisi surat suara sebelum menuju bilik suara. Peralatan Protokol Kesehatan di TPS juga telah dipersiapkan dimana pemilih akan menggunakan hak pilihnya dengan alat coblos yang telah disediakan, kemudian mencolos satu kali pada kolom yang berisi nomor urut, pas foto, dan nama pasangan calon. Berikutnya, pemilih akan memasukan surat suara ke dalam kotak sesuai jenis pemilihan dipandu oleh KPPS . Setelah selesai melakukan pencoblosan di bilik suara Pemilih membuka sarung tangan kemudian membuang sarung tangan ke tempat sampah yang telah disediakan di dekat meja KPPS dan usai membuang sarung tangan ke tempat sampah, pemilih akan diteteskan tinta ke salah satu jari, kemudian petugas di pintu keluar TPS akan memberitahukan bahwa setelah memilih wajib untuk mencuci tangan di tempat yang telah disediakan (Kompas.com, 2020).

KPU selaku Panitia Pemilihan Umum juga telah menetapkan masa kampanye berlangsung selama 71 hari, dimulai sejak 26 September dan berakhir 5 Desember 2020 . Pilkada Serentak 2020 akan digelar di 270 wilayah, dengan rincian sembilan provinsi, 37 kota, dan 224 kabupaten. Sebanyak 715 pasangan calon siap meramaikan Pilkada 2020 di 270 daerah. Dari 715 paslon, 24 di antaranya merupakan calon gubernur dan wakil gubernur yang tersebar di sembilan provinsi. Pada tingkat kabupaten/kota, terdapat 691 pasangan calon bupati dan wakil bupati.Serta calon wali kota dan wakil wali kota. Jumlah ini tersebar di 260 kabupaten/kota.KPU mencatat, dari 270 daerah yang menyelenggarakan Pilkada, daerah yang hanya terdapat 1 calon (calon tunggal) sebanyak 25 kabupaten/kota. Sementara itu, hari pemungutan suara pilkada rencananya dilaksanakan secara serentak pada 9 Desember 2020 (Tribunnews.com, 2020).

Penerapan manajemen krisis dalam penyelenggaraan Pilkada Serentak 2020 mutlak harus dilakukan. Dalam konteks pelaksanaan Pilkada Serentak di tengah pandemi COVID-19, manajemen krisis secara sederhana dapat dimaknai sebagai Pilkada Serentak dengan konsep new normal. Pilkada dengan konsep new normal adalah pelaksanaan pilkada dengan penerapan protokol kesehatan yang ketat. Setiap aktivitas, proses, dan tahapan pilkada harus sesuai dengan protokol kesehatan, termasuk ketika proses pelaksanaan hak suara di TPS. Begitu pula dengan kegiatan kampanye yang sebaiknya diatur secara jelas, tegas, ketat, dan aplikatif agar tidak menyebabkan terjadinya kerumunan dan pengumpulan massa (masyarakat). Kegiatan rapat koordinasi, sosialisasi, dan aktivitas lain yang berkenaan dengan proses penyelenggaraan Pilkada Serentak sebaiknya dilakukan secara daring, kecuali yang benar-benar harus dan 
membutuhkan pertemuan langsung (tatap muka), itu pun harus diatur sedemikian rupa. Sosialisasi dan kampanye (bagi para kandidat) juga dapat dilaksanakan lewat media sosial dan media massa. Media sosial dapat membantu sosialisasi informasi Pilkada Serentak secara masif, efisien, efektif, dan maksimal di tengah kondisi pandemi seperti sekarang, dimana pergerakan masyarakat sangat terbatas. Sosialisasi daring merupakan solusi dan kunci untuk dapat menyukseskan Pilkada Serentak 2020.

Pemerintah harus mengatur ketentuan Pilkada Serentak dengan sebaik-baiknya secara terukur dan aplikatif sampai akhir. Hal ini dikarenakan, berdasarkan penelitian, udara adalah salah satu media penyebaran COVID-19. Badan Kesehatan Dunia (WHO) pada 9 Juli 2020 mengungkapkan, transmisi atau penularan virus Sars-Cov-2 terjadi terutama melalui percikan/buliran air liur atau droplets, baik secara langsung maupun tidak. Dalam studi yang dilakukan, transmisi udara bisa terjadi pada prosedur yang menyebabkan aerosol seperti di fasilitas kesehatan. WHO mendefinisikan penularan lewat udara sebagai agen penularan yang ditimbulkan oleh penyebaran aerosol yang terbang di udara dalam jarak dan waktu yang lama. Teori ini membuktikan sejumlah droplets pernapasan mampu menghasilkan aerosol. Aerosol sendiri merupakan tetesan pernapasan yang sangat kecil sehingga mampu melayang di udara. Jadi, selama tidak dapat dihindari orang berkumpul, di ruangan sempit dan berpendingin udara, harus melakukan $3 \mathrm{M}$ (menggunakan masker, menjaga jarak, dan mencuci tangan). Ketua IDI Jawa Timur, dr. Sutrisno Sp.OG mengingatkan bahwa menjaga jarak saja tidak cukup, tetapi setiap orang sebaiknya menjauhi kerumunan (m.liputan6.com., 2020).

\section{Metode Penelitian}

Metode yang diterapkan dalam penelitian ini adalah penelitian survey yaitu mendefinisikan penelitian survey sebagai penelitian yang dilakukan pada populasi besar maupun kecil, sehingga ditemukan kejadian-kejadian relatif, distribusi dan hubunganhubungan antar variabel sosiologis maupun psikologis (Sugiyono, 2012). Desain penelitian dengan cross sectional melalui kuesioner yang dibagikan menggunakan google form dengan link https://bit.ly/SurveyPilkadaser yang di sebarkan melalui Watshap Group yang dapat menjangkau sampai diluar jawa selama empat hari dengan kreteria yang saat itu daerahnya melaksanakan Pilkada Serentak Baik untuk Pemilihan Calon Gubernur dan Calon Wakil Gubernur, Pemilihan Calon Walikota dan Calon Wakil Walikota juga Pemilihan Calon Bupati dan Calon Wakil Bupati. Metode pengambilan sampel yang digunakan dalam penelitian ini adalah probability sampling. Populasi dalam penelitian ini adalah seluruh responden sejumlah 130 yang mengisi google from dijadikan sebagai responden.

Untuk memperoleh data yang sesuai dengan apa yang diperlukan oleh peneliti, maka diperlukan suatu instrumen. Instrumen adalah alat atau fasilitas yang digunakan oleh peneliti dalam mengumpulkan data agar pekerjaannya lebih mudah dan hasilnya lebih baik, dalam arti cermat, lengkap dan sistematis sehingga lebih mudah diolah (Arikunto, 2014). Instrumen penelitian yang digunakan dalam penelitian ini adalah 
Kuisener Survey dengan tiga variabel pertanyaan yaitu Karakteristik Responden, Pilkada Serentak dan Pandemi Covid-19.

Penelitian ini dilakukan di Kabupaten Pati karena letaknya strategis membuat peneliti lebih mudah dalam penelitian, alasan peneliti memilih tempat ini karena pada waktu penelitian bertepatan dengan situasi darurat Virus Corona atau Covid 19 yang harus kerja di rumah (Work From Home) dan peneliti juga berdomisli di Kabupaten Pati Jawa Tengah.

\section{Hasil dan Pembahasan}

\section{A. Hasil Penelitian}

\section{Karakteristik Responden}

Tabel. 1

Distribusi Frekuensi berdasar Jenis Pilkada yang diikuti Pemilih dengan n (130)

\begin{tabular}{ccc}
\hline Jenis Pilkada & Jumlah & Prosentase \\
\hline $\begin{array}{c}\text { Pemilihan Calon } \\
\text { Gubernur dan Calon } \\
\text { Wakil Gubernur }\end{array}$ & 5 & $3,8 \%$ \\
\hline $\begin{array}{c}\text { Pemilihan Calon } \\
\text { Walikota dan Calon } \\
\text { Wakil Walikota }\end{array}$ & 49 & $37,7 \%$ \\
\hline $\begin{array}{c}\text { Pemilihan Calon Bupati } \\
\text { dan Calon Wakil Bupati }\end{array}$ & 76 & $58.5 \%$ \\
\hline Total & $\mathbf{1 3 0}$ & $\mathbf{1 0 0} \%$
\end{tabular}

Penjelasan Tabel. 1 diatas adalah Jenis Pilkada yang diikuti pemilih adalah Pemilihan Calon Bupati dan Calon Wakil Bupati jumlahnya tertinggi yaitu 76 $(58,5 \%)$ responden.

Tabel.2.

Distribusi Frekuensi berdasar Kreteria Pekerjaan Responden dengan n (130)

\begin{tabular}{c|cc}
\hline Kreteria Pekerjaan & Jumlah & Prosentase \\
\hline PNS & 91 & $70 \%$ \\
\hline Karyawan Swasta & 27 & $20,8 \%$ \\
\hline Pedagang & 4 & $3,1 \%$ \\
\hline Masih Sekolah & 3 & $2,3 \%$ \\
\hline Pegawai Bumn & 1 & $3,1 \%$ \\
\hline $\begin{array}{c}\text { Tidak Mempunyai Pekerjaan } \\
\text { Tetap }\end{array}$ & 4 & $\mathbf{1 0 0} \%$ \\
\hline Total & $\mathbf{1 3 0}$ &
\end{tabular}

Penjelasan Tabel.2 diatas adalah responden dengan Pekerjaan PNS jumlahnya paling tinggi yaitu 91 (70\%) responden dan yang paling rendah adalah responden dengan pekerjaan Pegawai BUMN yaitu $1(0,8 \%)$ responden.

Tabel.3.

Distribusi Frekuensi berdasar Kreteria Usia Responden dengan n (130)

\begin{tabular}{|c|c|c|}
\hline Kreteria Usia & Jumlah & Prosentase \\
\hline 17 Tahun -20 Tahun & 1 & $0,8 \%$ \\
\hline 21 Tahun -25 Tahun & 4 & $3,1 \%$ \\
\hline 26 Tahun -35 Tahun & 16 & $12,3 \%$ \\
\hline
\end{tabular}




\begin{tabular}{c|cc}
\hline Kreteria Usia & Jumlah & Prosentase \\
\hline 36 Tahun - 45 Tahun & 48 & $36,9 \%$ \\
\hline 46 Tahun - 55 Tahun & 48 & $36,9 \%$ \\
\hline Lebih dari 56 Tahun & 13 & $10 \%$ \\
\hline Total & $\mathbf{1 3 0}$ & $\mathbf{1 0 0} \%$ \\
\hline
\end{tabular}

Sumber: Data 2020

Penjelasan Tabel.3 diatas adalah responden dengan Usia 36 Tahun - 45 Tahun dan Usia 46 Tahun-55 Tahun memiliki jumlah tertingi yang sama yaitu $48(36,9 \%)$ dan responden terendah pada Usia 17 Tahun - 20 Tahun yaitu sejumlah $1(0,8 \%)$ responden.

Tabel. 4.

Distribusi Frekuensi berdasar Kreteria Pernah Menggunakan Hak Pilih dengan n (130) Kreteria Menggunakan Hak Pilih Jumlah Prosentase

\begin{tabular}{ccc}
\hline Baru Pertama kali & 5 & $3,8 \%$ \\
\hline Sudah Lebih Dari Satu Kali & 125 & $96,2 \%$ \\
\hline Total & $\mathbf{1 3 0}$ & $\mathbf{1 0 0} \%$ \\
\hline
\end{tabular}

Sumber: Data 2020

Penjelasan Tabel.4 diatas adalah responden yang sudah menggunakan hak pilih lebih dari satu kali jumlahnya tertinggi yaitu 125 (96,2\%) responden.

Tabel.5.

Distribusi Frekuensi Berdasarkan Daerah Pemilihan dengan n (130)

\begin{tabular}{|c|c|c|}
\hline Daerah Pemilihan & Jumlah & Prosentase \\
\hline Provinsi Riau & 1 & $0,8 \%$ \\
\hline Provinsi Sumatra Barat & 1 & $0,8 \%$ \\
\hline Kalimantan Utara & 1 & $0,8 \%$ \\
\hline Kota Semarang & 33 & $25,4 \%$ \\
\hline Kota Magelang & 4 & $3,1 \%$ \\
\hline Kota Surakarta & 3 & $2,3 \%$ \\
\hline Kota Pekalongan & 4 & $3,1 \%$ \\
\hline Kota Surabaya & 1 & $0,8 \%$ \\
\hline Kota Batam & 1 & $0,8 \%$ \\
\hline Kota Medan & 1 & $0,8 \%$ \\
\hline Kota Tangerang Selatan & 1 & $0,8 \%$ \\
\hline Kota Pasuruan & 3 & $2,3 \%$ \\
\hline $\begin{array}{r}\text { Kabupaten OKU Selatan } \\
\text { Sumsel }\end{array}$ & 1 & $0,8 \%$ \\
\hline Kabupaten Boyolali & 1 & $0,8 \%$ \\
\hline Kabupaten Pekalongan & 3 & $2,3 \%$ \\
\hline Kabupaten Kendal & 1 & $0,8 \%$ \\
\hline Kabupaten Wonogiri & 2 & $1,5 \%$ \\
\hline Kabupaten Semarang & 12 & $9,2 \%$ \\
\hline Kabupaten Purworejo & 4 & $3,1 \%$ \\
\hline Kabupaten Sukoharjo & 8 & $6,2 \%$ \\
\hline Kabupaten Sragen & 7 & $5,4 \%$ \\
\hline Kabupaten Rembang & 5 & $3,8 \%$ \\
\hline Kabupaten Bandung & 1 & $0,8 \%$ \\
\hline Kabupaten Musi Rawas & 2 & $1,5 \%$ \\
\hline Kabupaten Cianjur & 2 & $1,5 \%$ \\
\hline Kabupaten Grobogan & 3 & $2,3 \%$ \\
\hline Kabupaten Demak & 17 & $13,1 \%$ \\
\hline Kabupaten Klaten & 2 & $1,5 \%$ \\
\hline Kabupaten Sleman & 1 & $0,8 \%$ \\
\hline
\end{tabular}




\begin{tabular}{ccc}
\hline \multicolumn{1}{c}{ Daerah Pemilihan } & Jumlah & Prosentase \\
\hline Kabupaten Mamuju & 1 & $0,8 \%$ \\
\hline Kepulauan Riau & 2 & $1,5 \%$ \\
\hline Kabupaten Pohuwato & 1 & $0,8 \%$ \\
\hline Total & $\mathbf{1 3 0}$ & $\mathbf{1 0 0} \%$ \\
\hline
\end{tabular}

Sumber: Data 2020

Penjelasan Tabel. 5 diatas adalah responden pada daerah pemilihan Kota Semarang jumlahnya tertinggi yaitu $33(25,4 \%)$ responden.

2. Sebaran distribusi frekuensi tentang Pemilihan Kepala Daerah (Pilkada) serentak tanggal 9 desember tahun 2020

Tabel.6

Sebaran Jawaban tentang Apakah anda Tahu Sudah Masuk Dalam Daftar Pemilih Tetap (DPT) Pilkada Serentak 2020

\begin{tabular}{ccc}
\hline Kreteria Responden & Jumlah & Prosentase \\
\hline Belum Tahu & 1 & $0,8 \%$ \\
\hline Sudah Tahu & 129 & $99,2 \%$ \\
\hline Total & $\mathbf{1 3 0}$ & $\mathbf{1 0 0} \%$ \\
\hline
\end{tabular}

Sumber: Data 2020

Penjelasan Tabel. 6 pada sebaran jawaban tentang apakah anda tahu sudah masuk dalam Daftar Pemilih Tetap (DPT) Pilkada serentah 2020 didapatkan sejumlah $129(99,2 \%)$ responden menjawab sudah tahu dan hanya 1 $(0,8 \%)$ responden yang menjawab belum tahu.

Tabel.7

Sebaran Jawaban tentang Apakah anda termasuk dalam DPPh atau Daftar Pemilih Pindahan? (yaitu daftar yang berisi pemilih yang telah terdaftar dalam DPT, tetapi menggunakan hak pilihnya di TPS lain)

\begin{tabular}{c|cc}
\hline Kreteria Responden & Jumlah & Prosentase \\
\hline Tidak & 114 & $87,7 \%$ \\
\hline$Y a$ & 16 & $12,3 \%$ \\
\hline Total & $\mathbf{1 3 0}$ & $\mathbf{1 0 0 \%}$
\end{tabular}

Penjelasan Tabel.7 pada sebaran jawaban tentang Apakah anda termasuk dalam DPPh atau Daftar Pemilih Pindahan ? (yaitu daftar yang berisi pemilih yang telah terdaftar dalam DPT, tetapi menggunakan hak pilihnya di TPS lain) didapatkan sejumlah $114(87,7 \%)$ responden menjawab sudah Tidak dan 16 $(12,3 \%)$ responden yang menjawab Ya.

\section{Tabel.8}

Sebaran Jawaban tentang Apakah jarak TPS dari Tempat tinggal anda Mudah Dijangkau ?

\begin{tabular}{ccc}
\hline Kreteria Jarak Tps & Jumlah & Prosentase \\
\hline Sangat Mudah Terjangkau & 92 & $70,8 \%$ \\
\hline Mudah Terjangkau & 37 & $28,5 \%$ \\
\hline $\begin{array}{c}\text { Sulit Terjangkau ( Butuh } \\
\begin{array}{c}\text { Waktu dan Alat Transportasi } \\
\text { khusus untuk menuju ke TPS) }\end{array}\end{array}$ & 1 & $0,8 \%$ \\
\hline Total & $\mathbf{1 3 0}$ & $\mathbf{1 0 0} \%$ \\
\hline
\end{tabular}


Penjelasan Tabel.8 pada sebaran jawaban tentang Apakah Apakah jarak TPS dari Tempat tinggal anda Mudah Dijangkau? didapatkan sejumlah 92 (70,8\%) responden menjawab Sangat Mudah Terjangkau dan yang Sulit terjangkau (Butuh waktu dan Alat Transportasi khusus untuk menuju ke TPS) sejumlah $1(0,8 \%)$ responden.

Tabel.9

Sebaran Jawaban tentang Apakah anda Mendapatkan Surat undangan untuk para pemilih dalam bentuk Fomulir Model C yang sudah ada namanya di DPT?

\begin{tabular}{ccc}
\hline $\begin{array}{c}\text { Kreteria Mendapatkan } \\
\text { Surat Undangan }\end{array}$ & Jumlah & Prosentase \\
\hline $\begin{array}{c}\text { Sudah Mendapat Undangan } \\
\text { dari Panitia }\end{array}$ & 127 & $97,7 \%$ \\
\hline Belum Mendapat Undangan & 2 & $1,5 \%$ \\
\hline Hanya dengan e KTP & 1 & $0,8 \%$ \\
\hline Total & $\mathbf{1 3 0}$ & $\mathbf{1 0 0} \%$ \\
\hline
\end{tabular}

Sumber : Data 2020

Penjelasan Tabel 9 pada sebaran jawaban tentang Apakah anda Mendapatkan Surat undangan untuk para pemilih dalam bentuk Fomulir Model C yang sudah ada namanya di DPT? didapatkan sejumlah 127 (97,7\%) responden menjawab sudah mendapat undangan dari panitia dan $1(0,8 \%)$ responden yang hanya menggunakan e-KTP

Tabel.10

Sebaran Jawaban tentang Apakah Anda Hadir untuk Menggunakan Hak Pilih anda Di TPS pada Hari Rabu Tanggal 9 Desember 2020 dalam Pilkada Serentak ?

\begin{tabular}{ccc}
\hline Kreteria Kehadiran & Jumlah & Prosentase \\
\hline Hadir & 120 & $92,3 \%$ \\
\hline $\begin{array}{c}\text { Tidak Hadir karena } \\
\text { Pekerjaan yang tidak dapat } \\
\text { ditinggalkan }\end{array}$ & 6 & $4,6 \%$ \\
\hline TIDAK HADIR & 4 & $3,1 \%$ \\
\hline Total & $\mathbf{1 3 0}$ & $\mathbf{1 0 0} \%$ \\
\hline
\end{tabular}

Sumber : Data 2020

Penjelasan Tabel.10 pada sebaran jawaban tentang Apakah Anda Hadir untuk Menggunakan Hak Pilih anda Di TPS pada Hari Rabu Tanggal 9 Desember 2020 dalam Pikada Serentak? didapatkan sejumlah 120 (92,3\%) responden menjawab HADIR dan $4(3,1 \%)$ responden TIDAK HADIR dalam Pilkada serentak tanggal 9 Desember 2020.

\section{Sebaran Distribusi Frekuensi tentang Pandemi Covid-19}

Tabel.11

Sebaran Jawaban tentang Apakah anda tahu kondisi perkembangan Kasus Covid 19 di Daerah anda baik di Provinsi, Kabupaten kota dan Di tempat tinggal anda saat ini?

\begin{tabular}{ccc}
\hline Kreteria Responden & Jumlah & Prosentase \\
\hline Sangat Tahu & 120 & $92,3 \%$ \\
\hline Kurang Tahu & 6 & $4,6 \%$ \\
\hline Tidak Mau Tahu & 4 & $3,1 \%$ \\
\hline Total & $\mathbf{1 3 0}$ & $\mathbf{1 0 0} \%$ \\
\hline
\end{tabular}

Sumber : Data 2020 
Penjelasan Tabel.11 pada sebaran jawaban tentang Apakah anda tahu kondisi perkembangan Kasus Covid 19 di Daerah anda baik di Provinsi, Kabupaten kota dan Di tempat tinggal anda saat ini? didapatkan sejumlah 120 $(92,3 \%)$ responden menjawab Sangat Tahu dan 4 (3,1\%) responden Tidak Mau Tahu masalah perkembangan COVID-19 di daerah responden.

Tabel.12

Sebaran Jawaban tentang Saat ini di daerah Tempat Tinggal anda status Covid 19 nya ada pada zona apa?

\begin{tabular}{ccc}
\hline Kreteria Zona Covid 19 & Jumlah & Prosentase \\
\hline Zona Merah & 85 & $65,4 \%$ \\
\hline Zona Hijau & 13 & $10 \%$ \\
\hline Zona Kuning & 27 & $20,8 \%$ \\
\hline Tidak Tahu & 5 & $3,8 \%$ \\
\hline Total & $\mathbf{1 3 0}$ & $\mathbf{1 0 0} \%$
\end{tabular}

Penjelasan Tabel 12 pada sebaran jawaban tentang Saat ini di daerah Tempat Tinggal anda status Covid 19 nya ada pada zona apa? didapatkan sejumlah $85(65,4 \%)$ responden menjawab Merah dan $5(3,8 \%)$ responden menjawab Tidak Tahu Zona Covid-19 di daerahnya saat ini.

Tabel 13

Sebaran Jawaban tentang Apakah TPS di tempat anda Tinggal, sudah Menerapkan Protokol Kesehatan Covid 19 baik untuk petugas TPS,Alat Peraga, Pelaksanaan Pemilihan dan Juga Pada Pemilih nya?

\begin{tabular}{ccc}
\hline $\begin{array}{c}\text { Kreteria Protokol } \\
\text { Kesehatan }\end{array}$ & Jumlah & Prosentase \\
\hline $\begin{array}{c}\text { Sudah dan Sangat } \\
\text { Maksimak }\end{array}$ & 95 & $73,1 \%$ \\
\hline $\begin{array}{c}\text { Sudah Tapi Tidak } \\
\text { Maksimal }\end{array}$ & 34 & $26,2 \%$ \\
\hline $\begin{array}{c}\text { Tidak Menerapkan Protokol } \\
\text { Kesehatan }\end{array}$ & 1 & $0,8 \%$ \\
\hline Total & $\mathbf{1 3 0}$ & $\mathbf{1 0 0} \%$ \\
\hline
\end{tabular}

Penjelasan Tabel 13 pada sebaran jawaban tentang Apakah TPS di tempat anda Tinggal, sudah Menerapkan Protokol Kesehatan Covid 19 baik untuk petugas TPS,Alat Peraga, Pelaksanaan Pemilihan dan Juga Pada Pemilih nya? didapatkan sejumlah $95(73,1 \%)$ responden menjawab Sudah dan Sangat Maksimal dan $1(0,8 \%)$ responden menjawab Tidak Menerapkan Protokol Kesehatan pada TPS di wilayahnya.

\section{B. Pembahasan}

Akhirnya tanggal 9 Desember 2020 bertepatan di hari Rabu Pilkada Serentak di Indonesia jadi dilaksanakan, ditengah kritikan dan kekawatiran para Akademisi dan Pakar Kesehatan Epidemiologi tentang Protokol Kesehatan dalam Pencegahan dan Penanggulangan Pandemi Covid-19 di Indonesia. Seperti yang di Sampaikan oleh Mahfud MD selaku Menkopolhukam, dalam jumpa pers secara daring yang 
dilaksanakan pada tanggal 9 Desember 2020 sekitar pukul 13.45 WIB, mengatakan Pilkada serentak secara umum sudah berjalan "cukup baik" yaitu sudah sesuai protokol kesehatan Covid-19. Hal ini didasarkan nformasi yang dihimpun oleh Badan Nasional Penanggulangan Bencana (BNPB) Temuan awal ini, menurut Mahfud, menjadi bagain informasi sekaligus menepis kekhawatiran sejumlah kalangan yang menganggap penyelengaraan Pilkada 2020 akan menjadi klaster baru penyebaran Covid-19.12

Hal ini selaras dengan survey yang dilakukan Peneliti bahwa berdasarkan analisa karakteristik responden yang ada adalah, peran serta responden dalam Pilkada Serentak Tahun 2020 ini sangat bervariasi. Dari indikator Jenis Pilkada yang diikuti Pemilihan Calon Bupati dan Calon Wakil Bupati memiliki jumlah yang tertinggi yaitu $76(58,5 \%)$ responden dari total responden 130 responden. Hal ini di sebabkan karena jumlah Kabupaten di Indonesia lebih banyak yaitu 224 Kabupaten yang tahun ini menyelenggarakan Pilkada Serentak. Sedangkan dari Jenis Pekerjaan PNS juga tertinggi dalam jumlah responden yaitu 91 (70\%) responden, hal ini menunjukan kepesertaan PNS dalam menyukseskan Pilkada Serentak Tahun 2020 ini sangat signifikan. Pada sebaran usia pemilih didapatkan bahwa sebaran usia pemilih sangat variatif mulai dari usia 17 Tahun-20 Tahun sampai usia lebih dari 56 Tahun juga ikut dalam Pilkada Serentak tahun ini, meskipun jumlah tertinggi responden adalah pada usia 36 Tahun-45 Tahun dan juga 46 Tahun-55 Tahun dengan jumlah 48 $(36,9 \%)$ responden dari total responden 130. Pada indikator berapa kali pemilih dalam menggunakan hak pilih dalam Survey ini didaptkan hanya $5(3,8 \%)$ responden dari jumlah total responden 130, hal ini menunjukan bahwa minat pemilih pemula dalam Pilkada Serentak Tahun 2020 ini masih sangat rendah sehingga menjadi perhatian KPU untuk kedepan bisa lebih gencar melakukan sosialisasi kepada Pemilih Pemula untuk bisa lebih aktif dalam pelaksanaan pemilihan umum.

Pada Analisa Variabel Pilkada Serentak Tahun 2020 dalam penelitian survey ini didapatkan bahwa sejumlah 129 (99,2\%) responden sudah tahu bahwa pemilih masuk dalam Daftar Pemilih Tetep (DPT) artinya bahwa DPT yang ada sudah tersosialisasikan dengan baik kepada calon pemilih hal ini diharapkan akan memaksimalkan tingkat kehadiran pemilih ke Tempat Pemungutan Suara (TPS) . Sedangakan Pemilih yang masuk dalam DPPH atau Daftar Pemilih Pindahan yaitu daftar yang berisi pemilih yang telah terdaftar dalam DPT, tetapi menggunakan hak pilihnya di TPS lain juga terdata yaitu ada $16(12,3 \%)$ responden, hal ini menunjukan bahwa Panitia Pemilihan juga memperhatikan calon pemilih pindahan untuk tetap dapat menggunakan hak pilihnya secara langsung, bebas dan rahasia. Pada Indikator Jarak TPS dari pemilih juga menjadi perhatian dalam penelitian survey ini, dimana didapatkan bahwa $92(70,8 \%)$ responden menyatakan TPS yang ada Sangat Mudah terjangkau dan $37(28,5 \%)$ responden menyatakan jarak TPS Mudah Terjangkau artinya bahwa KPPS (Kelompok Panitia Pemungutan Suara) setempat sangat memperhatikan kerterjangkauan TPS untuk efisiensi waktu dan jarak tempuh dari rumah calon pemilih ke TPS yang ada, sehingga diharapkan tingkat kehadiran serta 
partisipasi calon pemilih dalam Pilkada Serentak Tahun 2020 ini sangat bermakna dan signifikan. Disamping itu sejumlah 127 (97\%) responden dari 130 responden juga menyatakan bahwa calon pemilih telah mendapatkan surat undangan dalam bentuk Formulir Model $\mathrm{C}$ yang sudah ada namanya di DPT, hal ini menunjukan bahwa KPPS telah melaksanakan tahapan pemilihan dengan baik. Hal yang Paling Penting dalam Survey ini adalah didapatkan tingkat Kehadiran Pemilih dalam menggunakan Hak Pilih di TPS tanggal 9 Desember 2020 sangat tinggi yaitu responden yang hadir adalah $120(92,3 \%)$ dari 130 responden dan sejumlah $6(4,6 \%)$ tidak hadir karena pekerjaa yang tidak dapat ditinggalkan serta hanya $4(3,1 \%)$ responden yang menyatakan tidak hadir. Hal ini menunjukan bahwa tingkat partisispasi pemilih masih sangat tinggi meskipun saat ini masih dalam suasana pandemi COVID-19. Semoga ini menjadi awal yang baik dalam proses mendapatkan figur pemimpin yang amanah, adil dan tidak Korupsi serta mampu melanjutkan uapaya dalam menjalankan roda Pemerintahan di daerahnya.

Pada Analisa Variabel Pandemi COVID-19 didapatkan bahwa responden sudah sangat paham dan mengerti kondisi pandemi yang terjadi saat ini,terbukti bahwa sejumlah $120(92,3 \%)$ responden menyatakan sangat tahu dengan kondisi perkembangan Kasus COVID-19 di daerahnya baik di Provinsi, Kabupaten dan Kota tempat responden berada. Disamping itu Pilkada Serentak Tahun 2020 saat ini daerah responden juga masih di selimuti Pandemi terbukti sejumlah $85(65,4 \%)$ responden menyatakan daerahnya masuk dalam Zona Merah dan $27(20,8 \%)$ reponden masuk dalam Zona Kuning, hal ini menunjukan bahwa Pandemi COVID19 masih mewarnai dalam Pilkada Serentak Tahun 2020 ini. Sedangkan yang berhubungan dengan Penerapan Protokol Kesehatan di TPS dalam survey ini didapatkan gambaran yang signifikan dimana dari 130 responden menyatakan 95 $(73,1 \%)$ responden menyatakan TPS yang didaerahnya Sudah dan Sangat Maksimal dalam menerapkan Prokes dan 34 (26,2\%) responden menyatakan Sudah melaksanakan Protokol Kesehatan meski tidak maksimal, artinya KPU melalui KPPS telah memperhatikan keselematan calon Pemilih di TPS dalam pencegahan penyebaran Kasus COVID-19 sehingga diharapkan setelah pelaksanaan Pilkada Serentah Tahun 2020 tidak ada Kluster baru dari TPS yang ada. Dan kita juga berharap seusai Pilkada Serentak ini tidak ada laporan penambahan kasus baru baik untuk Petugas, Pemilih dan juga keluarganya.

\section{Kesimpulan}

Pada Analisis Variabel Karakteristik responden yang terdiri dari lima indikator didapatkan pada indikator berapa kali responden menggunakan hak pilih didapatkan bahwa responden pemula masih rendah yaitu $5(3,8 \%)$ responden baru pertama kali mengikuti Pilkada Serentak, selaras demgan indikator usia bahwa usia pemilih pemula yaitu usis 17 Tahun-20 Tahun didapatkan $1(0,8 \%)$ responden.

Pada Analisa Variabel Pilkada Serentak Tahun 2020 yang terdiri dari lima indikator didapatkan bahwa secara keseluruhan hasil ditiap indikator sangat signifikan 
dengan sebaran di atas $80 \%$ dan Pada tingkat Kehadiran di dapatkan 120 (92,3\%) responden menyatakan Hadir di TPS untuk menggunakan Hak Pilihnya di Pilkada Serentak Tahun 2020.

Pada Analisa Variabel Pandemi COVID-19 yang terdiri dari tiga indikator didapatkan bahwa daerah responden saat ini sejumlah $85(65,4 \%)$ responden menyatakan pada Zona Merah dan 27 (20,8\%) responden menyatakan pada Zona Kuning dan Protokol Kesehatan di TPS sejumlah $95(73,1 \%)$ responden menyatakan Sudah dan Sangat Maksimal dalam menerapkan Prokes di TPS tempat responden memilih.

\section{BIBLIOGRAFI}

Ahclak Asmara, Yasa. (2018). Partisipasi Politik Masyarakat pada Pilkada Serentak 2015 di Kabupaten Gowa (Studi terhadap Pemilih Pemula di Kel. Batang Kaluku Kec. Somba Opu Kab. Gowa). Universitas Islam Negeri Alauddin Makassar.

Arikunto, Suharsimi. (2014). Prosedur Penelitian: Suatu Pendekatan Praktik. Jakarta: Rineka Cipta.

katadata.co.id. (2020). Belajar dari Sukses Korsel Gelar Pemilu Saat Corona untuk Pilkada 2020. Retrieved from https://katadata.co.id/muhammadridhoi/berita/5ea67 f719300d/belajar-dari-sukses-korsel-gelar-pemilu-saat-corona-untuk-pilkada-2020.

Kennedy, Richard, \& Suhendarto, Bonaventura Pradana. (2020). Diskursus Hukum: Alternatif Pola Pengisian Jabatan Kepala Daerah di Masa Pandemi Covid-19. Jurnal Pembangunan Hukum Indonesia, 2(2), 188-204.

Kompas.com. (2020). Ini Tata Cara Pemilihan di TPS Saat Pilkada di Masa Pandemi Covid-19. Retrieved from https://nasional.kompas.com/read/2020/11/12/0004461/ ini-tata-cara-pemilihan-di-tps-saat-pilkada-di-masa-pandemi-covid-19?page=all

m.liputan6.com. (2020). IDI Jatim: Selain Jaga Jarak, Hindari Kerumunan untuk Cegah COVID - 19. Retrieved from https://m.liputan6.com/surabaya/read/4310873 /idi-jatim-selain-jaga-jarak-hindari-kerumunan-untuk-cegah-covid-19

Mas'udi, Wawan, \& Winanti, P. S. (2020). Tata Kelola Penanganan COVID-19 di Indonesia: Kajian Awal. Yogyakarta: GajahMada Pers.

merdeka.com. (2020). Data Terkini Jumlah Korban Virus Corona di Indonesia. Retrieved from https://www.merdeka.com/peristiwa/data-terkini-korban-covid-19di-indonesia-november-2020.html.

Pratiwi, A., Mulamukti, Ajheng, Pertiwi, Mahesti, \& Andriany, Anissa Rizky. (2020). Hubungan Subjective Well Being dengan komitmen organisasi pada pekerja yang melakukan work from home di masa pandemi Covid 19. Syntax Idea, 2(11), 824833.

Saputro, Agus. (2018). Agama dan Negara: politik identitas menuju Pilpres 2019. 
Asketik: Jurnal Agama dan Perubahan Sosial, 2(2), 111-120.

Sugiyono. (2012). Metode Penelitian Kuantitatif Kualitatif \& RND. Bandung: Alfabet.

Sutrisno, Cucu. (2017). Partisipasi Warga Negara Dalam Pilkada. JPK (Jurnal Pancasila Dan Kewarganegaraan), 2(2), 36-48.

Tribunnews.com. (2020). Daftar 270 Daerah yang Gelar Pilkada Serentak 2020 pada Rabu, 9 Desember 2020, Adakah Daerahmu? Retrieved from https://www.tribunnews.com/nasional/2020/12/03/daftar-270-daerah-yang-gelarpilkada serentak-2020-pada-rabu-9-desember-2020-adakah-daerahmu.

Wardhana, Dharendra. (2020). Kajian Kebijakan dan Arah Riset Pasca-Covid-19. The Indonesian Journal of Development Planning, 4(2), 223-239.

Yunus, Nur Rohim, \& Rezki, Annissa. (2020). Kebijakan Pemberlakuan Lock Down Sebagai Antisipasi Penyebaran Corona Virus Covid-19. Salam: Jurnal Sosial Dan Budaya Syar-I, 7(3), 227-238. 